\title{
Summer mortalities and detection of ostreid herpesvirus microvariant in Pacific oyster Crassostrea gigas in Sweden and Norway
}

\author{
Stein Mortensen ${ }^{1, *}$, Åsa Strand ${ }^{2}$, Torjan Bodvin ${ }^{3}$, Anders Alfjorden ${ }^{4}$, \\ Cecilie K. Skår ${ }^{1}$, Anders Jelmert ${ }^{3}$, Anna Aspán ${ }^{4}$, Lisbeth Sælemyr ${ }^{1}$, \\ Lars-Johan Naustvoll ${ }^{3}$, Jon Albretsen ${ }^{3}$ \\ ${ }^{1}$ Institute of Marine Research, PO Box 1870 Nordnes, 5817 Bergen, Norway \\ ${ }^{2}$ Department of Marine Sciences, Göteborg University, Tjärnö, 45296 Strömstad, Sweden \\ ${ }^{3}$ Institute of Marine Research, Flødevigen Research station, Nye Flødevigveien 20, 4817 His, Norway \\ ${ }^{4}$ National Veterinary Institute, Sweden (SVA), Department of Animal Health and Antimicrobial Strategies, 75189 Uppsala, \\ Sweden
}

\begin{abstract}
The Pacific oyster Crassostrea gigas has recently expanded its range in Scandinavia. The expansion is presumably a result of northwards larval drift. Massive settlements were recorded in many areas along the Swedish west coast and southern Norway in 2013 and 2014. After the spawning season in 2014 , the temperature of the surface water peaked at $24-26^{\circ} \mathrm{C}$. After this period, high and sudden mortalities occurred in a Swedish hatchery and in wild populations along the Swedish west coast and south coast of Norway. Surveys and collected data showed that mortalities mainly occurred during $3 \mathrm{wk}$ in September. All size classes were affected, and affected populations displayed a patchy distribution with heavily affected and unaffected populations in close proximity. Flat oysters Ostrea edulis and blue mussels Mytilus edulis were unaffected. Ostreid herpesvirus (OsHV) was detected in moribund Pacific oyster spat as well as in surviving adults. The virus was identified as OsHV-1 $\mu$ var. This is the first detection of this variant in Scandinavia, showing that OsHV-1 $\mu$ var is present in areas with recent establishments of Pacific oysters, and where there is no aquaculture of this species.
\end{abstract}

KEY WORDS: Pacific oysters · Crassostrea gigas - Summer mortalities $\cdot$ Scandinavia $\cdot$ Ostreid herpesvirus · OsHV-1 $\mu$ var

\section{INTRODUCTION}

The Pacific oyster Crassostrea gigas is native to the Pacific Ocean (Nehring 2006, Miossec et al. 2009). It has been introduced to bivalve-producing areas worldwide, either to replace stocks of indigenous oysters depleted by harvesting or affected by diseases (Grizel \& Heral 1991, Wolff \& Reise 2002, Reise et al. 2005, Ruesink et al. 2005), or to create a new industry. It has also been introduced to new areas incidentally by passive transport (Eno et al. 1997). Self-sustaining populations have established in many new areas (Reise 1998, Diederich et al. 2005). The Pacific oyster was introduced to Denmark, Sweden, and Norway for aquaculture trials in the late 1970s (Wrange et al. 2010). Although oysters were released or left in abandoned farms or dispatch centers, this did not result in establishment of wild populations until the 1990s, when Pacific oysters were observed in the Danish Wadden Sea 
(Diederich et al. 2005, Wrange et al. 2010). In 2006 and 2007, massive settlements occurred on the Swedish west coast and in some areas in southern Norway (Wrange et al. 2010). The populations thereafter declined during 2009 to 2011 due to cold winters (Strand et al. 2012), but rapidly recovered with local spawning and massive settlements in 2013 and 2014. In September 2014, high mortalities of spat were recorded in a Swedish hatchery producing Pacific oyster seed. This was followed up by inspections in the field and registration of mortalities at several sites in the area. Here we describe the event and possible causes of the mortalities. depth (WTW Ecoline LF 170 with conductivity and temperature sensors). SSTs in Sweden were recorded hourly at $1 \mathrm{~m}$ depth at Tjärnö (TidbiT loggers, Hobo; Onset) and east of the Koster Islands (Swedish Meteorological and Hydrological Institute; SMHI), by a surface buoy with a multi-sensor (Water Quality Monitor, Wet Labs). Surface temperatures in the area were found to be unusually warm during the summer and early autumn 2014 . While temperatures reached $20-22^{\circ} \mathrm{C}$ in the open ocean, temperatures in shallow inshore areas peaked at $24-26^{\circ} \mathrm{C}$ in late July and decreased gradually thereafter.

Phytoplankton composition and abundance was monitored in the Oslo fjord and along the Norwegian Skagerrak coast as part of the Norwegian monitoring

\section{METHODS AND RESULTS}

\section{Registration of mortalities}

On 12 September 2014, high mortality $(>90 \%)$ of Pacific oyster spat was observed at an oyster culture facility at Koster, Sweden $\left(58^{\circ} 53^{\prime} 45^{\prime \prime} \mathrm{N}\right.$, $11^{\circ} 2^{\prime} 47^{\prime \prime}$ E). Following this event, additional mortalities at several other sites along the Swedish and Norwegian coasts were observed by researchers from the University of Gothenburg and the Institute of Marine Research (IMR), and reports from the public regarding sites with dead oysters were received at research and governmental organizations (Fig. 1). The observed mortalities were patchy in distribution, with closely located sites $(<1 \mathrm{~km})$ displaying large differences in the number of affected individuals. At some sites, no mortality was observed, at some sites only juveniles were affected, and at some sites all size classes of oysters were affected. No mortalities of the native flat oyster Ostrea edulis or blue mussel Mytilus edulis were observed.

\section{Environmental data}

Summer sea surface temperatures (SSTs) at 4 sites in the inner Oslo fjord were recorded 4 times daily during daytime, and hourly values were recorded in the outer Oslo fjord at $1 \mathrm{~m}$

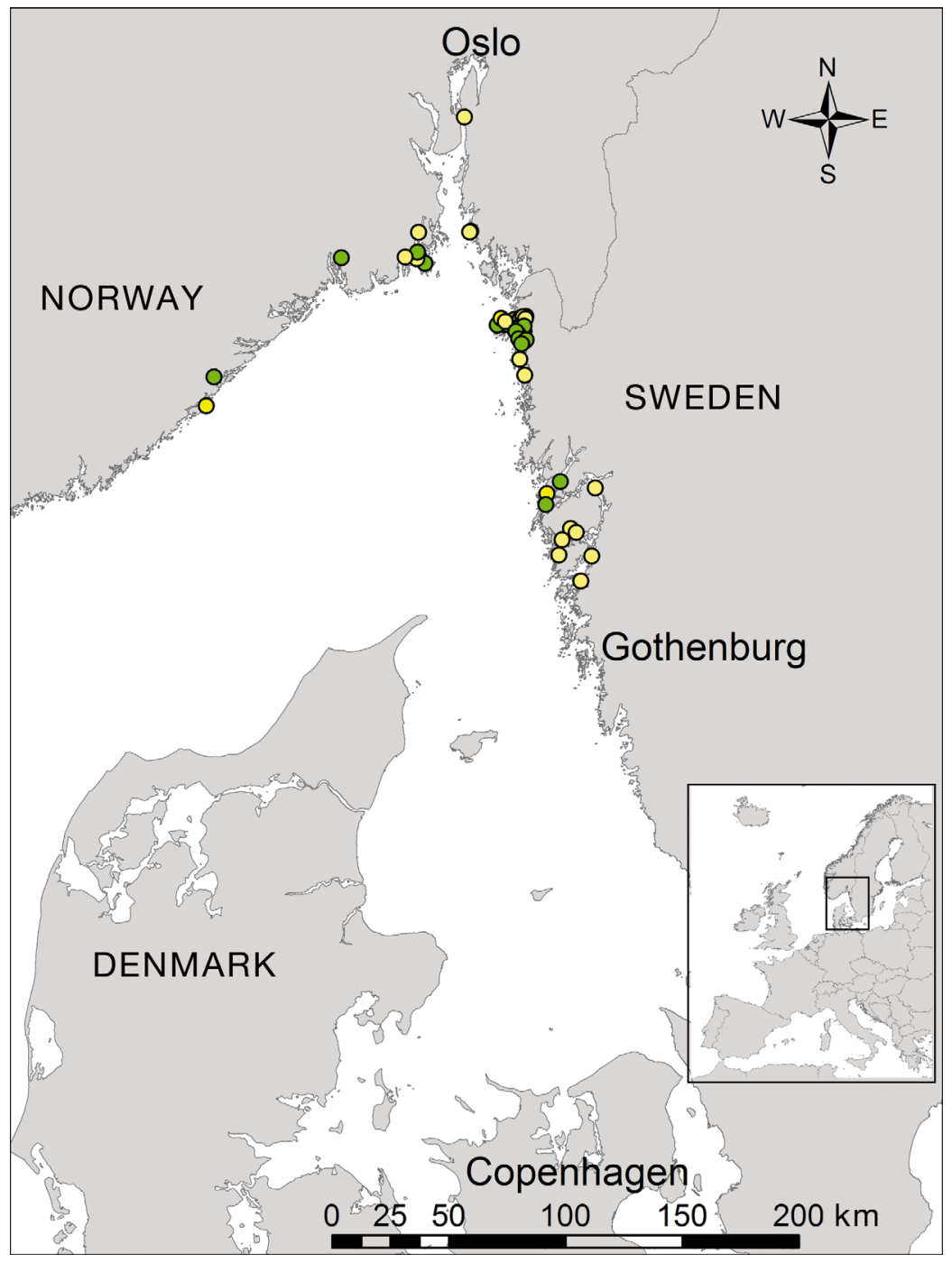

Fig. 1. Sites surveyed by researchers and oyster farmers, and public reports regarding mortalities of Pacific oysters Crassostrea gigas in Sweden and Norway during autumn 2014. Green markings indicate sites with no mortality; yellow markings indicate sites with mortalities 
program for harmful algae and by the environmental monitoring program conducted by IMR. Samples were collected from the upper $5 \mathrm{~m}$, preserved with natural Lugol's solution, and analyzed by microscopy. The phytoplankton composition in the Swedish part of Skagerrak and Kattegat was analyzed by SMHI, once in September and once in October. Phytoplankton abundances were not high during August to October, except for some shorter blooms. From midSeptember, the concentrations of dinoflagellates increased. During August and September, toxin-producing phytoplankton were present at a few stations, but in low abundance. Dictyocha fibula and D. speculum increased in September, with maximum concentrations in mid-October. These species may occur in 2 forms, viz. 'naked' or with a silica skeleton; we mainly observed the naked variant in Sweden. No additional rare or alarming findings were reported from the phytoplankton analysis.

\section{Tissue sampling}

During the initial mortality at Koster, Sweden, on 12 September, moribund and newly dead spat were sampled and preserved in $70 \%$ ethanol and Davidson's fixative (Shaw \& Battle 1957). Fresh material was sent to the National Veterinary Institute (SVA) in Sweden where the oyster spat were examined as squash samples by direct microscopy. Dorso-ventral tissue cross-sections were cut from 6 spat and fixed in Davidson's fixative, embedded in paraffin, sectioned at $3 \mu \mathrm{m}$, stained with hematoxylin-eosin saffron and observed at 100 to $400 \times$ magnification. Two spat which were alive upon arrival were sampled whole and frozen before DNA extraction. Adult wild oysters from 2 affected populations (Trälsundet and Saltösundet) and 2 unaffected populations (Krokesundet and Svallhagen) in Sweden were sampled on 22 and 23 September. Tissue was preserved in $70 \%$ ethanol, and in isotone formalin, and sent to SVA. Live oysters from 2 unaffected populations at Fjällbacka and Lysekil in Sweden were sampled by the Swedish National Food Agency on 23 October and sent to SVA. At Hui, Norway, 20 surviving Crassostrea gigas, $2 \mathrm{M}$. edulis, and $5 \mathrm{O}$. edulis were collected on 25 September. In addition, 3 C. gigas from Tvedestrand, where no mortality was observed, were included. The bivalves were transported live to IMR; pieces of mantle and gill tissues from each specimen were preserved in tubes with $96 \%$ ethanol and RNALater, respectively. Dorso-ventral tissue sections were processed and observed as described above. A summary of collected samples is provided in Table 1.

\section{DNA isolation, PCR, and sequencing}

Detection of OsHv $\mu$ var was performed according to Schikorski et al. (2011): 10 to $30 \mathrm{mg}$ of ethanolfixed mantle tissue pieces were air-dried for 1 to $2 \mathrm{~h}$ at room temperature before total DNA was extracted from the tissue using a QIAmp DNA Mini kit (Qiagen) according to the manufacturer's protocol. Final elution of DNA was performed with $50 \mu \mathrm{l}$ of nuclease-free water, and DNA concentrations were calculated; samples were then stored at $4^{\circ} \mathrm{C}$. Real-time PCR was run using the primers HVDP-F/HVDP-R (Webb et al. 2007). At IMR, a minor modification was performed by using 100 ng DNA samples in the real-

Table 1. Summary of Pacific oyster Crassostrea gigas samples collected for histological investigation and ostreid herpesvirus-1 (OsHV-1) analysis

\begin{tabular}{|c|c|c|c|c|c|c|}
\hline \multirow[t]{2}{*}{ Site } & \multicolumn{2}{|c|}{ Co-ordinates } & \multirow{2}{*}{$\begin{array}{c}\text { Date } \\
\text { (yr-mo-dd) }\end{array}$} & \multicolumn{2}{|c|}{ Mortality estimation -} & \multirow{2}{*}{$\begin{array}{l}\text { OsHV-1 } \\
\text { detected }\end{array}$} \\
\hline & $\mathrm{N}$ & E & & At site $(\%)$ & Method & \\
\hline \multicolumn{7}{|l|}{ Sweden } \\
\hline Svallhagen & $58.8684^{\circ}$ & $11.1555^{\circ}$ & 2013-08-13 & 5 & $0.5 \mathrm{~m}^{2}$ square $(\mathrm{n}=155)$ & + \\
\hline Koster & $58.8967^{\circ}$ & $11.0491^{\circ}$ & 2014-09-12 & 50 & Observations 100 random individuals & + \\
\hline Svallhagen & $58.8684^{\circ}$ & $11.1555^{\circ}$ & 2014-09-22 & 0 & Visual estimation & - \\
\hline Krokesundet & $58.8615^{\circ}$ & $11.1741^{\circ}$ & 2014-09-23 & 0 & $0.5 \mathrm{~m}^{2}$ square $(\mathrm{n}=5)$ & - \\
\hline Trälsundet & $58.9130^{\circ}$ & $11.1968^{\circ}$ & $2014-09-23$ & 56 & $0.5 \mathrm{~m}^{2}$ square $(\mathrm{n}=5)$ & + \\
\hline Saltösundet & $58.8743^{\circ}$ & $11.1459^{\circ}$ & $2014-09-23$ & 78 & $0.5 \mathrm{~m}^{2}$ square $(\mathrm{n}=5)$ & + \\
\hline Fjällbacka & $58.5925^{\circ}$ & $11.2683^{\circ}$ & $2014-10-23$ & 0 & Visual estimation & + \\
\hline Lysekil & $58.3083^{\circ}$ & $11.4503^{\circ}$ & $2014-10-23$ & 0 & Visual estimation & + \\
\hline \multicolumn{7}{|l|}{ Norway } \\
\hline Hui & $59.1260^{\circ}$ & $10.3656^{\circ}$ & $2010-09-23$ & 11 & $1 \mathrm{~m}^{2}$ square $(\mathrm{n}=20)$ & + \\
\hline Hui & $59.1260^{\circ}$ & $10.3656^{\circ}$ & $2013-08-13$ & 76 & $1 \mathrm{~m}^{2}$ square $(\mathrm{n}=8)$ & - \\
\hline Hui & $59.1260^{\circ}$ & $10.3656^{\circ}$ & 2014-09-25 & 76 & $1 \mathrm{~m}^{2}$ square $(\mathrm{n}=5)$ & + \\
\hline Tvedestrand & $58.5893^{\circ}$ & $8.9411^{\circ}$ & 2014-09-27 & 0 & Visual estimation & + \\
\hline
\end{tabular}


time PCR reactions. To confirm the presence of OsHv-1 $\mu$ var in positive samples, the primer pairs IA1/IA2, C2/C6, and OHVC/OHVD were used in the standard PCR and sequencing (Segarra et al. 2010, Lynch et al. 2013). After analyzing the oysters sampled in September 2014, 8 archived ethanol-fixed mantle tissue samples from $C$. gigas collected at Hui in October 2010 and 60 mantle tissue samples from C. gigas collected at Hui and Svallhagen in midAugust 2013 were processed and tested for OSHV-1 as described above.

\section{PCR results}

In the samples collected in 2014, OsHV-1 was detected in spat from Koster, as well as in 17 adults from Hui, 2 from Tvedestrand, 3 from Saltösundet, 2 from Trälsundet, 1 from Fjällbacka, and 1 from Lysekil (Table 1). OsHV-1 was not detected in samples from 2 of the unaffected sites (Svallhagen and Krokesundet). Sequences from the positive Norwegian samples and from the Swedish samples from Trälsundet and Saltösundet obtained using the C2/C6 primers were identical to the reference strain (HQ842610), and confirmed the presence of OsHV-1 $\mu$ var (Fig. 2). Samples from Fjällbacka and Lysekil were not sequenced. From the archived material, a single sample from 2010 was OsHV-1 positive, and in the samples from 2013, 3 oysters from Svallhagen were positive (Table 1). Sequencing revealed differences from the 2014 samples in ORF4 (Fig. 2).

\section{Histology and bacteriology}

At SVA, cultivation of Vibrio spp. was performed on spat from Koster, according to standard methods. DNA samples were amplified for the $r p o B$ gene for detection of Vibrio spp. according to the method described by Ki et al. (2009). At IMR, a V. aestuarianus real-time PCR was performed as described by
McCleary \& Henshilwood (2015). Aliivibrio fischeri and $V$. gigantis were isolated from tissue samples from the first oyster sampling during the initial mortality outbreak on 12 September. $V$. aestuarianus was not detected. The 20 Pacific oysters from Hui appeared in a reduced physiological state, with empty gonads, low glycogen reserves, and passive digestive tissues in diverticulae. In 1 specimen, patchy, focal necrosis was observed in the digestive diverticulae and surrounding connective and storage tissues. The 3 specimens from Tvedestrand and 10 surviving oysters from Saltösundet had a normal appearance, with gametes in gonads, higher glycogen reserves, and active digestive tissues. Several oysters from the Swedish sites exhibited post mortem changes, including bacterial infiltrations in tissues and the presence of ciliates in the digestive system. Traces of spikes, presumably from Dictyocha sp., were observed in spat from Koster.

\section{DISCUSSION}

The main mortality occurred during a few weeks in September, although reports from the public indicate an earlier onset of mortality at some sites. The mortalities were extremely patchy in distribution, and severely affected sites were often located close to unaffected sites. Although the recent establishments of Pacific oysters overlap native populations of flat oysters and blue mussels, these species were apparently unaffected. Mortalities followed a general pattern as described for summer mortalities of Pacific oysters, occurring in warm periods, when the oysters' energetic resources are low and the energy demand is high (Pernet et al. 2010, 2014, EFSA AHAW Panel 2015, Petton et al. 2015). This disease has been attributed to a combination of factors; pathogens (OsHV-1) and pathogenic Vibrio species (in particular $V$. aestuarianus), physiological state (spawning stress or low energy reserves), and environmental factors (such as elevated temperature or

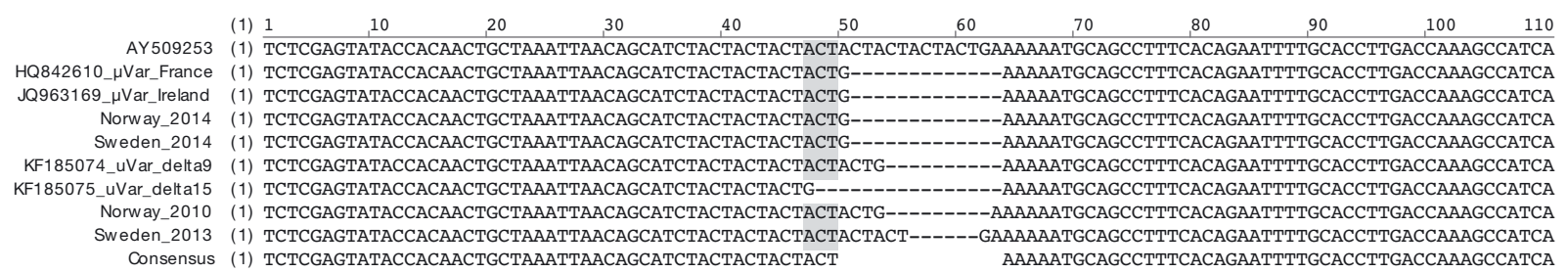

Fig. 2. Aligned DNA sequences from the C region amplified by the C2/C6 and OHVC/OHVD primer pairs, starting at bp 613, comparing the Scandinavian genotypes to the ostreid herpesvirus-1 (OsHV-1) reference (AY509253), OsHV-1 $\mu$ var genotypes from France and Ireland, and the OsHV-1 $\mu$ var $\Delta 9$ and $\Delta 15$ variants (Martenot et al. 2012) 
the presence of toxic microalgae) affecting the physiological status or modulating the immune defense (EFSA AHAW Panel 2015).

The observed mortalities occurred between 9 and 30 September, after the spawning season in 2014, and a few weeks after the temperature of the surface water peaked at $24-26^{\circ} \mathrm{C}$. Oysters may thus have been weakened, and hence more susceptible to infections, after the spawning season, and thereafter exposed to temperatures that were optimal for disease transmission, infection, and development (Pernet et al. 2012, Petton et al. 2013).

OsHV-1 was detected in spat from the hatchery at Koster, and in adults from Hui, Tvedestrand, Trälsundet, Saltösundet, Fjällbacka, and Lysekil (Table 1). The virus was identified as OsHV-1 $\mu$ var (Segarra et al. 2010), a variant considered particularly virulent for Pacific oysters and which has been detected in an increasing number of oyster-producing areas in Europe since 2008 (Segarra et al. 2010, Martenot et al. 2011, EFSA AHAW Panel 2015). All year classes were affected, a finding that is not consistent with previous reports, where mainly young oysters suffered high mortalities during the summer mortality events (Dégremont et al. 2010, Petton et al. 2013).

The source of the virus is unknown. The Pacific oyster has expanded its range in Scandinavia since 2006 (Wrange et al. 2010). As no recent aquaculture of Pacific oysters has been carried out, the expansion is presumably a result of larval drift (Laugen et al. 2015). However, the possibility exists that re-seeding of imported oysters for aquaculture trials in the $1970 \mathrm{~s}$ or 1980s, or for human consumption, may have added to the establishment in some areas. Since 2007, the densities of oysters have increased, and recruitment in 2013 and 2014 was highly successful. Ostreid herpesvirus may be transmitted horizontally, from shedders to susceptible oysters (Schikorski et al. 2011, Petton et al. 2015), although it is not known over which distances infectious virus may be carried. Besides the favorable abiotic conditions, a contributing cause of the summer mortality may be the recently established high densities of oysters, facilitating disease transmission both between individuals and between populations. It is noteworthy that OsHV-1 $\mu$ var was detected in oysters from Tvedestrand, Lysekil, and Fjällbacka that appeared in a good physiological state and originated from populations where no mortalities were recorded. The water temperature was within the optimal range for transmission of OsHV-1 $\left(16-21^{\circ} \mathrm{C}_{\text {; }}\right.$ Petton et al. 2015) in the entire surveyed area in August and September 2014. Virus may have propagated in infected oysters, shed, and thereafter been spread widely. The virus may infect larvae (Le Deuff et al. 1994), and dispersal of infected larvae may thus be a source of spreading to new areas.

The patchy pattern indicates that some unknown factor(s) may have triggered the propagation of the virus and development of disease. Several episodes with currents of south-flowing surface waters were observed during the period from 9 to 16 September, causing a sudden drop in salinity that might have influenced the spat in the hatchery (data not shown). These south-flowing currents might coincide with the first reports of mortalities. It is unlikely that the mortality was influenced by the presence of toxic phytoplankton. The species composition and the abundance during autumn 2014 were defined as normal, and the concentration of toxin-producing species was too low to have any negative effect on oysters. Dictyocha spp. have been linked to fish mortalities, but they were only present from late September and formed high biomass in October, after the period with oyster mortality. However, observed diatoms and traces of spicules that might have originated from Dictyocha spp. in oysters from Koster indicate the presence of these algae earlier, which may have acted as a stressor.

Analyses of the archived samples from 2010 and 2013 show that other variants of OsHV-1 were present in Pacific oysters in the region before the summer mortality event in 2014, presumably without causing mortalities. The present detection of OsHV-1 $\mu$ var is the first in Scandinavia, and suggests that OsHV-1 $\mu v a r$ has expanded to areas with recent establishments of Pacific oysters, and where there is no aquaculture of this species, except from the hatchery at Koster. Further investigation is needed in order to establish whether OsHV-1 $\mu$ var is present in the native bivalve fauna in Scandinavia or has been introduced with imported oysters or via larvae drifting northwards.

Acknowledgements. Thanks to Ingrid U. Fiksdal for preparation of histological slides; Stéphane Villoing and Egil Karlsbakk for help with sequence data; Leif Ove Finnerud (http://badevann.no) for permission to use temperature data; Oddbjørn Pettersen at NIVA for the temperature record at Solbergstrand; Fredrik Waldh at SMHI for making the Koster buoy data accessible; Kent Berntsson, Anders Karlsson, Benno Jönsson, Agnes Faxén, and Susanne Lindegarth for assistance in collecting field data and tissue samples; and to everyone who reported their observations to us. This work was supported by The Nordic Council of Ministers (NORDEN), grant 44/13, HaV through grant 3219-14 to the National Veterinary Institute, Sweden (SVA), and FORMAS through grant 2011-1132 to Å.S. 


\section{LITERATURE CITED}

Dégremont L, Boudry P, Ropert M, Samain JF, Bédier E, Solethnik P (2010) Effects of age and environment on survival of summer mortality by two selected groups of the Pacific oyster Crassostrea gigas. Aquaculture 299: $44-50$

- Diederich S, Nels G, van Beusekom JEE, Reise K (2005) Introduced Pacific oysters (Crassostrea gigas) in the northern Wadden Sea: invasion accelerated by warm summers. Helgol Mar Res 59:97-106

EFSA AHAW Panel (European Food Safety Authority Panel on Animal Health and Welfare) (2015) Scientific opinion on oyster mortality. EFSA J 13:4122

Eno NC, Robin A, Sanderson CVG (1997) Non-native marine species in British waters: a review and directory. Joint Nature Conservation Committee, Peterborough

Grizel H, Heral M (1991) Introduction into France of the Japanese oyster (Crassostrea gigas). J Cons Int Explor Mer 47:399-403

Ki JS, Zhang R, Zhang W, Huang YL, Qian PY (2009) Analysis of RNA polymerase beta subunit (rpoB) gene sequences for the discriminative power of marine Vibrio species. Microb Ecol 58:679-691

Laugen A, Hollander J, Obst M, Strand A (2015) The Pacific Oyster (Crassostrea gigas) invasion in Scandinavian coastal waters in a changing climate: impact on local ecosystem services. In: Canning-Clode J (ed) Biological invasions in changing ecosystems - vectors, ecological impacts, management and predictions. De Gruyter Open, Berlin, p 230-246

Le Deuff RM, Nicolas JL, Renault T, Cochennec N (1994) Experimental transmission of herpes-like virus to axenic larvae of Pacific oyster, Crassostrea gigas. Bull Eur Assoc Fish Pathol 14:69-72

Lynch SA, Dillane E, Carlsson J, Culloty S (2013) Development and assessment of a sensitive and cost-effective polymerase chain reaction to detect ostreid herpesvirus 1 and variants. J Shellfish Res 32:657-664

- Martenot C, Oden E, Travauille E, Malas JP, Houssin M (2011) Detection of different variants of ostreid herpesvirus 1 in the Pacific oyster, Crassostrea gigas, between 2008 and 2010. Virus Res 160:25-31

Martenot C, Fourour S, Oden E, Jouaux A, Travaillé E, Malas JP, Houssin M (2012) Detection of the OsHV-1 uvar in the Pacific oyster Crassostrea gigas before 2008 in France and description of two new microvariants of the Ostreid Herpesvirus 1 (OsHV-1). Aquaculture 338341:293-296

McCleary S, Henshilwood K (2015) Novel TaqMan ${ }^{\circledR}$ MGB real-time PCR for sensitive detection of Vibrio aestuarianus in Crassostrea gigas. Dis Aquat Org 114:239-248

Miossec L, Le Deuff RM, Goulletquer P (2009) Alien species alert: Crassostrea gigas (Pacific oyster). ICES Coop Res Rep 299:1-42 pp

Nehring S (2006) NOBANIS - invasive alien species fact sheet Crassostrea gigas. Online Database of the North European and Baltic Network on Invasive Alien Species - NOBANIS. Available at https://www.nobanis.org/ globalassets/speciesinfo/c/crassostrea-gigas/crassostreagigas.pdf

Pernet F, Barret J, Marty C, Moal J, Le Gall P, Boudry P
(2010) Environmental anomalies, energetic reserves and fatty acid modifications in oysters coincide with an exceptional mortality event. Mar Ecol Prog Ser 401: 129-146

> Pernet F, Barret J, Le Gall P, Corporeau C and others (2012) Mass mortalities of Pacific oysters Crassostrea gigas reflect infectious diseases and vary with farming practices in the Mediterranean Thau lagoon, France. Aquacult Environ Interact 2:215-237

$>$ Pernet F, Lagarde F, Jeannée N, Daigle G and others (2014) Spatial and temporal dynamics of mass mortalities in oysters is influenced by energetic reserves and food quality. PLoS ONE 9:e88469

> Petton B, Pernet F, Robert R, Boudry P (2013) Temperature influence on pathogen transmission and subsequent mortalities in juvenile Pacific oysters Crassostrea gigas. Aquacult Environ Interact 3:257-273

> Petton B, Boudry P, Alunno-Bruscia M, Pernet F (2015) Factors influencing disease-induced mortality of Pacific oysters Crassostrea gigas. Aquacult Environ Interact 6: 205-222

Reise K (1998) Pacific oysters invade mussel beds in the European Wadden Sea. Senckenb Marit 28:167-175

Reise K, Dankers N, Essink K (2005) Introduced species. In: Essink K, Dettmann C, Farke H, Laursen K, Luerßen G, Marencic H, Wiersinga W (eds) Wadden Sea quality status report 2004. Common Wadden Sea Secretariat, Wilhelmshaven, p 155-161

Ruesink JL, Lenihan HS, Trimble AC, Heiman KW, Micheli F, Byers JE, Kay MC (2005) Introduction of non-native oysters: ecosystem effects and restoration implications. Annu Rev Ecol Evol Syst 36:643-689

Schikorski D, Faury N, Pepin JF, Saulnier D, Tourbiez D, Renault T (2011) Experimental ostreid herpesvirus 1 infection of the Pacific oyster Crassostrea gigas: kinetics of virus DNA detection by q-PCR in seawater and in oyster samples. Virus Res 155:28-34

> Segarra A, Pépin JF, Arzul I, Morga B, Faury N, Renault T (2010) Detection and description of a particular Ostreid herpesvirus 1 genotype associated with massive mortality outbreaks of Pacific oysters, Crassostrea gigas, in France in 2008. Virus Res 153:92-99

$>$ Shaw BL, Battle HI (1957) The gross and microscopic anatomy of the digestive tract of the oyster Crassostrea virginica (Gmelin). Can J Zool 35:325-347

Strand Å, Blanda E, Bodvin T, Davids JK and others (2012) Impact of an icy winter on the Pacific oyster (Crassostrea gigas Thunberg, 1793) populations in Scandinavia. Aquat Invasions 7:433-440

- Webb SC, Fidler A, Renault T (2007) Primers for PCR-based detection of ostreid herpes virus-1 (OsHV-1): application in a survey of New Zealand molluscs. Aquaculture 272: 126-139

Wolff WJ, Reise K (2002) Oyster imports as a vector for the introduction of alien species into northern and western European waters. In: Leppäkoski E, Gollasch $\mathrm{S}$, Olenin $\mathrm{S}$ (eds) Invasive aquatic species of Europe. Distribution, impacts and management. Kluwer, Dordrecht, p 193-205

- Wrange AL, Valero J, Harkestad LS, Strand $\varnothing$ and others (2010) Massive settlements of the Pacific oyster, Crassostrea gigas, in Scandinavia. Biol Invasions 12:11451152

Submitted: July 7, 2015; Accepted: October 27, 2015

Proofs received from author(s): December 15, 2015 